A WORLDLY AFFAIR 
This page intentionally left blank 


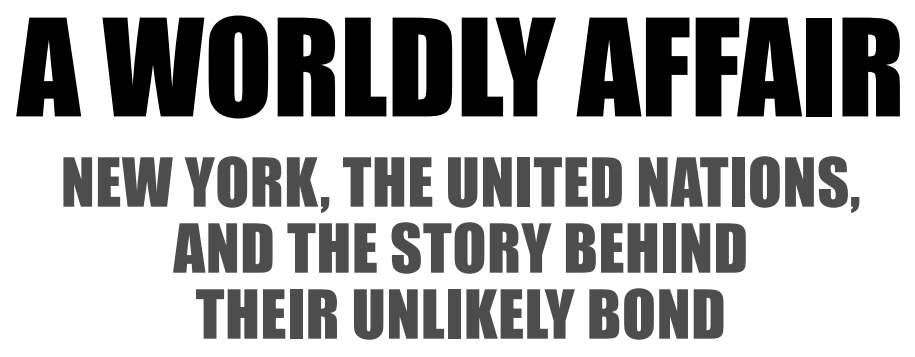

\section{PAMELA HANLON}

Empire State Editions

An imprint of Fordham University Press

ESE New York 2017 
Copyright (C) 2017 Pamela Hanlon

All rights reserved. No part of this publication may be reproduced, stored in a retrieval system, or transmitted in any form or by any means-electronic, mechanical, photocopy, recording, or any other-except for brief quotations in printed reviews, without the prior permission of the publisher.

Fordham University Press has no responsibility for the persistence or accuracy of URLs for external or third-party Internet websites referred to in this publication and does not guarantee that any content on such websites is, or will remain, accurate or appropriate.

Fordham University Press also publishes its books in a variety of electronic formats. Some content that appears in print may not be available in electronic books.

Visit us online at

www.empirestateeditions.com

www.fordhampress.com

Library of Congress Cataloging-in-Publication Data

available online at http://catalog.loc.gov.

Printed in the United States of America

$\begin{array}{llllllll}19 & 18 & 17 & 5 & 4 & 3 & 2 & 1\end{array}$

First edition 